\title{
The After-Acquired Surety: Commercial Paper
}

\author{
Roscoe Steffen* \\ Richard S. E. Johns***
}

When a lender, for whatever reason, decides he must have additional security for a borrower's note or other obligation, there are several options. The borrower, or someone for his accommodation, may give the lender tangible security-bonds, share certificates, or commercial paper-by way of pledge. Or, again, the accommodation party may merely sign the principal obligation held by the lender, as comaker, endorser, or acceptor, thus, ostensibly, giving the lender a contract obhigation as security.

The well-advised creditor, of course, has customarily given new consideration for the after-acquired contract surety. The borrower's note may be renewed for another year, or certain collateral may be released; this much would be due any party to a simple contract, but the surety has always been accorded a special status. ${ }^{1}$ The pledge has been treated as something else again; even when given for accommodation, it has never required a consideration, to be effective as such. ${ }^{2}$

But the case is not all that simple. When commercial paper is pledged there will be the contract obligations of the parties to consider. Again, if the debtor, or one of his accommodating friends, purports to pay the obligation, the creditor may find himself holding after-acquired contract obligations, should the payment iten be dishonored. This Article exainines the various devices, the basic question being whether, or the extent to which, the Uniform Commercial Code may have changed prior law. ${ }^{3}$

* Professor of Law, University of California, Hastings; John P. Wilson Professor of Law, Emeritus, University of Chicago. A.B. 1916, College of Idaho; LL.B. 1920, Yale University; LL.D. 1956, College of Idaho.

*: Bigelow Fellow, University of Chicago. B.A. 1968, University of Cahifornia, Santa Barbara; J.D. 1971, University of California, Hastings.

1. See G. Osborne, Cases on Secured Transactions 7 et seq. (1967).

2. Wigmore, The Pledge Idea, 10 HaRv. L. REv. 321, 389 (1897).

3. For an able study see Peters, Suretyship Under Article 3 of UCC, 77 YaIE L.J. 833 (1968). 


\section{The CONTRACT SURETY}

The often-cited, pre-Code case of Bank of Carrollton v. Latting ${ }^{4}$ will illustrate one aspect of the problem on the contract side. The plaintiff bank had taken the note of its customer, Carrollton Cotton Oil Company, to cover an overdraft of $\$ 948$. Then, some 10 days 1ater, the bank asked Latting, an officer of Cotton Oil, to endorse the note for the maker's accommodation-which he did.5 At the trial, it was established that there was no consideration whatever for Latting's endorsement; he did not sign pursuant to prior agreement, nor was there any extension of time, release of collateral, or other concession. The court, without much debate, held that Latting was not liable: "There must, of legal necessity, be a sufficient consideration in order to render valid the contract of suretyship or guaranty."

That the Code draftsmen "intended" to change this law admits of no doubt. Indeed, comment 3 to section $3-415(2)$ says just that: "Subsection (2) is intended to change occasional decisions holding that there is no sufficient consideration where an accommodation party signs a note after it is in the hands of a holder who has given value." Of course, the comment is correct when it says that there have been only "occasional decisions" holding as the court did in Carrollton, but it is less than candid if it means to suggest that such decisions are in a minority. The point has been too well settled, for too long, to allow of more than an "occasional" holding. 8

However, with adoption of the Code, a number of writers, also, have stated, in effect, that Carrollton and related cases are no longer good law. ${ }^{9}$ Whether they reached that position in reliance on the comment or on the text of section $3-415(2)$ is usually not made clear. Hawkland, for example, simply asserts broadly that

4. 37 Okla. 8, 130 P. 144, 44 L.R.A. (n.s.) 481 (1913); Annot., 167 A.I.R. 2d 1174 (1947).

5. The report is silent as to the bank's purpose: Perhaps the borrower's credit had worsened; a bank officer may have been on the carpet for not following usual procedures; a visit from the bank examiner was expected; or the bank may have wanted to dress up the paper for rediscount purposes. Indeed, the mere fact that there was no consideration indicates that Latting really signed for the bank's accommodation, and so without liability. UNIFORM COMMRRCIAL CODE $\$ 3-415(5)$ [hereinafter cited as U.C.C.J.

6. 37 Okla. at 10, 130 P. at 144,44 L.R.A. (n.s.) at 485.

7. U.C.C. $\$ 3-415(2)$, Comment 3 (second sentence).

8. See W. BRTtron, HaNdBook of the LaW of Bilis and Notes 221-33 (2d ed. 1961) [hereinafter cited as BrItTon].

9. E.g., Cosway, Negotiable Instruments-A Comparison of Washington Law and the U.C.C., 43 WASH. L. REV. 499, 519, 532 (1968); Helstad, The Impact of the U.C.C. in Michigan, 53 Mrch. L. Rev. 171, 190, 199 (1954). Compare Barak, The Uniform Commercial Code-Commercial Paper, 3 IsRaed L. Rev. 7, 28 n.20 (1968). 
[i]n the usual suretyship situation, the surety must be given an independent consideration if the principal obligation is due or if the obligee has extended credit prior to the promise of the surety. But the law of commercial paper is different in this regard, because promises to pay antecedent obligations are regarded under this law as being supported by consideration. ${ }^{10}$

Of course, the Code is very careful, in most places at least, to say that "value" and "consideration" are two quite different concepts. ${ }^{11}$ In that respect the Code conforms to prior law; section 25 of the Negotiable Instruments Law, it will be remembered, provided that "[v]alue is any consideration sufficient to support a simple contract. An antecedent or preexisting debt constitutes value . . ."12 But Hawkland makes the point that, as he sees it, a taker for value before maturity may today recover on the contract of an after-acquired surety, without bothering at all about consideration.

There have been no Code decisions, but some dicta, to the same effect. Perhaps Franklin National Bank v. Eurez Construction Corp..$^{13}$ should be histed as a decision that no consideration is necessary; the point is not clear. In that case both the accommodation maker and an accommodation endorser of a $\$ 20,000$ note defended on the ground that they had signed "as an accommodation to defendant, Eurez and without consideration." 14 But the Eurez Construction Corp., the payee, had thereafter transferred the note to plaintiff bank, and "though it was not indorsed on behalf of Eurez, the proceeds of the note were credited to the Eurez account on that day and thereafter were drawn against by that corporation." 15

Thus, there was an abundance of consideration in the usual sense, and the case might well have been put on that ground. But defendants appear to have urged a quibble-that they were due a personal consideration. In any case, the court expressly found that the accommodation parties had signed "the note in suit as an accommodation to defendant Eurez and without consideration . . . ."16 Perhaps the court meant "without consideration" in the paid surety sense, but it did not say so.

Judgment for plaintiff was given on the sole stated ground that, under section 3-415(1) and (2), "absence of consideration is not avail-

10. W. Hawkland, A Transactional Guide to the U.C.C. 561 (1964).

11. See, e.g., U.C.C. $\$ 3-303(b)$, Comment 2. N.I.L.].

12. NeGotiable Instruments LAW $\$ 25$ (emphasis added) [hereinafter cited as

13. 60 Misc. 2d 499, 301 N.Y.S.2d 845 (1969). See also First Nat'1 City Bank v. Valentine, 7 U.C.C. REP. SERV. 53 (N.Y. 1969).

14. 60 Misc. $2 d$ at 501,301 N.Y.S.2d at 848.

15. 1d., 301 N.Y.S.2d at 847.

16. 1d., 301 N.Y.S.2d at 848 (emphasis added). 
able as a defense to an accommodation inaker or indorser when the instrument is taken for value before it is due."17 The court may have felt bound to put the case on that ground, since the bank, as a "taker" without endorsement, could not qualify as a "holder" in due course. Moreover, there was a claim, not supported by the evidence, that Eurez had diverted the paper from the agreed use. This defense, too, could be cut off by the decision ${ }^{18}$ if the court's construction of section 3-415(2) was correct.

II

U.C.C. $\S 3-415$ (1) AND (2)

It is time to examine the text of section $3-415$ (1) and (2), to see what change, if any, has actually been made. Perhaps the writers of the second sentence of comment 3 , quoted above, ${ }^{19}$ let what they "intended" to say obscure what was in fact provided. At all events, subsection (2) reads as follows: "When the instrument has been taken for value before it is due the accommodation party is liable in the capacity in which he has signed even though the taker knows of the accommodation."20

Subsection (1) defines "accommodation party" in the abstract; lie is one who signs "in any capacity" for the purpose of lending his name. $^{21}$ The time when he signs, or for whose accommodation, is not material at that point. But subsection (2) then continues with a particular case: "When the instrument has been taken for value before it is due...." In that situation, "the accommodation party is liable in the capacity in which he has signed . . .."22 Not as he may thereafter sign, but as he "has" signed. The subsection, therefore, may fairly be said to speak only of an accommodation party who is on the paper when it is taken for value. It thus says nothing at all about an after-acquired surety, in the Carrollton sense.

The draftsmen of article 3 were skilled and fully able to say explicitly whrat they meant. Had they written what comment 3 says they "intended" to say, ${ }^{23}$ the provision easily could have been worded in this way (italicized words being new): "When the instrument has

17. $I d$.

18. The point is highly dubious, as Justice Meyer fully recognized, for it could give a mere taker for value equal or greater rights than a holder in due course. See Brannan, Some Necessary Amendments of the Negotiable Instruments Law, 26 HARV. L. REv. 493 (1913).

19. See text accoinpanying note 7 supra.

20. U.C.C. $\$ 3-415(2)$.

21. U.C.C. \$ $3-415(1)$.

22. U.C.C. \$ 3-415(2) (emphasis added).

23. Maybe they did, but were "yoted down." See note 36 infra. 
been taken for value before it is due an accommodation party then on the instrument or who signs at any later time is liable in the capacity in which lie has signed ...."24 But the subsection was not written in that way, and no legislature adopted in that form.

Long ago, Justice Holmes told us, in Swift \& Co. v. United States, ${ }^{25}$ that a writing, a bill in equity in that case, "is to be taken to mean what it fairly conveys to a dispassionate reader by a fairly exact use of English speech."26 Holmes made no allowance at all for what the writer may have "imtended" to say. We believe that "a dispassionate reader" of section 3-415(2), as adopted, expecting a "fairly exact use of English speech," would never so much as guess that it had anything to do with an after-acquired surety. The "intended" version of section 3-415(2), therefore, fails the first test.

If there still are doubts, however, Justice Jackson writes that in such cases "courts will construe the details of an act in conformity with its dominating general purpose . . . ."27 While the Code states some broad general purposes, not in question here, ${ }^{28}$ there is no statement of purposes tailored to article 3. For two centuries and more, lowever, the courts have pretty much agreed that commercial paper and its related law have been fashioned "for the convenience of trade and commerce." As has been said unore pointedly elsewhere, this policy "was not to favor any particular member of the commercial community, not banks, nor buyers or sellers, as such, but to facilitate 'trade and commerce.' $" 30$

Examined in the light of such a "dominating" purpose, and we

24. Perhaps the draftsmen did not want to grant that an endorser may sign after maturity. A futile effort is made in U.C.C. $\$ 3-108$, by omitting the last sentence of N.I.L. $\$ 7$, to stamp out the practice. But, of course, there may be a need, at times, to endorse an overdue instrument, with liability on demand to subsequent parties. $C f$. U.C.C. \& 3-501(4).

25. 196 U.S. 375 (1905).

26. Id. at 395. See also FTC v. Keppel \& Bros., 291 U.S. 304, 313 (1934), where Justice Stone said that "the normal meaning of the word," the word "unfair" im that case, "is the first criterion of statutory construction . ..." Holmes was careful to say his rule applied, however the Sherman Act might be construed. Keppel would indicate that in the case of either statute or bill in equity, the first test is much the same.

27. SEC v. C.M. Joiner Leasing Corp., 320 U.S. 344, 350-51 (1943) (construing the word "security" in the Securities Act of 1933).

28. U.C.C. $\$ 1-102$. Perhaps subsection (2)(a) is involved, as one of the purposes there stated is "to simplify, clarify and modernize" the law of commercial transactions. It is quite doubtful, as discussed above, that $\S 3-415(2)$ has done much either to "simplify" or to "clarify" the law. And we doubt that a purpose to "modernize" will, or should, justify giving banks and other large creditors a brand new advantage over unwary sureties.

29. See Pillans \& Rose v. Van Mierop \& Hopkins, 97 Eng. Rep. 1035, 1040 (K.B. 1765).

30. R. Steffen, Cases on Commercial and Investment Paper 5 (3d ed. 1964). 
know of none more accurate, ${ }^{31}$ the "intended" version of section 3415(2) fares no better. We do not have a Miller $v$. Race ${ }^{32}$ situation, where a Lord Mansfield could cut off the equities of a prior true owner, in favor of "an inn-keeper" who had taken the stolen paper "bona fide, in his business from a person who made an appearance of a gentleman." ${ }^{33}$ Here the transaction has ended, and the paper has come to rest in the hands of some bank or other creditor. Surely it does not facilitate trade or commerce to give such a holder a windfall recovery against an after-acquired surety; the dominating general purpose of article 3 is not to provide a trap for the unwitting.

\section{III}

\section{STATUTORY TeXT OR COMMENT}

So we reach the question: when text and cominent conflict, which prevails? The ouly possible answer, of course, is that text controls. ${ }^{34}$ The issue surfaced early in Code proceedings and was met clearly. The 1952 draft of section 1-102(3)(f) provided: "The Comments ... Inay be consulted in the construction and application of this Act but if text and comment conflict, text controls."35 That provision was omitted from the 1962 draft, without explanation, but probably also without any change in stance. ${ }^{36}$

This, of course, does not mean that comments are of little or no importance. On the contrary, they can be invaluable in giving background and understanding. It was the Reporter's hope, in fact, that by full and careful explanation it would be possible to avoid conflicting decisions of the sort that plagued the N.I.L., and even destroyed

31. Judge Wyzanski regards the Code "less as a novel enactment than as largely a restatement and clarificatiou of existing law which has the approval of American scholars." Universal C.I.T. Credit Corp. v. Guaranty Bank \& Trust Co., 161 F. Supp. 790,792 (D. Mass. 1958). This is helpful, even though written on the unlikely premise that construction will not be needed.

32. 97 Eng. Rep. 398 (K.B. 1758).

33. Id. at 401. Lord Mansfield also said that "he had uo sort of doubt" that the action was well brought, this "upon the general course of business, and froin consequences to trade and commerce: which would be much incommoded by a contrary determination." Id.

34. Otherwise, it might be argued there was an unwarranted delegation of legislative authority. See Schechter Poultry Corp. v. United States, 295 U.S. 495 (1935).

35. U.C.C. \$ 1-102(3)(f) (1952 version). Consider the Federalist Papers, which have been of great value as an aid in interpreting the Constitution, but which do not control.

36. The process by which the Code was put together is best described in Llewellyn, Why a Commercial Code, 22 TenN. L. Rev. 779, 782 (1953): On occasion, when the draftsman's proposed text was voted down by the Cominissioners, "we at least got the thing set up so that we are allowed to state in accompanying connments where the particular sections are trying to go:" 
uniformity in inany cases..$^{37}$ But comments were never to be a crutch for faulty draftsmanship.

Moreover, it is a question, when the comment itself is confused, whether any rehance at all may be put on it. For instance, the first sentence of comment 3 , which we have been discussing, makes this observation: "The obhgation of the accommodation party is supported by any consideration for which the instrument is taken before it is due."38 With all due respect, the critical time is before delivery to the payee or other taker; the inoney advanced at that time is the consideration for which the surety has bargained. The point is very simple and not in conflict. ${ }^{39}$ Even the cases where the surety has signed after delivery, but pursuant to prior agreement, are no exception. ${ }^{40}$

The comment then continues, saying in the second and third sentences, as above discussed, that the section was "intended" to impose hability on an accommodation party who may have signed after delivery, provided the paper was taken at soine time before it becaine due by "a holder who has given value." 41 The fourth sentence lets the cat out of the bag: "This is consistent with the provisions as to antecedent $o b$ ligations as consideration (Section 3-408)." ${ }^{\prime 2}$ With all due respect once more, this is sadly confused; the writer of the comment has no mandate to change long-settled prior law; a preexisting debt may be "value," but it emphatically is not "consideration." Comment of that sort is revealing, but it is not worth much.

What to do? The Code gives an answer in section 1-103: "Unless displaced by the particular provisions of this Act, the principles of

37. See Turner, A Factual Analysis of Certain Proposed Amendments, 38 YALE L.J. 1047 (1929).

38. U.C.C. $\$ 3-415(2)$, Comment 3 (emphasis added). Probably this phrase was used to overturn such cases as Marling v. Jones, 138 Wis. 82, 119 N.W. 931 (1909), and Altfillisch v. McCarty, 49 S.D. 203, 207 N.W. 67 (1926), about which there was once much controversy. See J.D. Brannan, Negotiable Instruments LAW 286 et seq. (4th ed. 1926). The "consideration" in each case was ample, but the instrument had been first delivered after maturity, and it was argued, though it was not so held, that a transfer at that time was so far out of line with the accommodation party's expectations as to constitute an improper diversion. Plainly the phrase "before it is due," in \$ 3-415(2), reads on those facts; it has no sensible bearing on consideration.

39. See, e.g., CaI. Civ. CODE $\$ 2792$ (West 1954):

Where a suretyship obligation is entered into at the same time with the original obligation .... and forms with that obligation a part of the consideration to the creditor, no other consideration need exist.

40. See Heuertematte v. Morris, 101 N.Y. 63, 70, 4 N.E. 1, 4 (1885), where an accommodation acceptor did not sign until after the draft had been taken by the payee:

The payment to the drawer of the purchase-price furmishes a good cousideration for the acceptance which he then undertakes shall be made, and its subsequent performanee by the drawee is only the fulfillment of the contract which the drawer represents he is authorized by the drawee to make.

41. U.C.C. $\$ 3-415(2)$, Comment 3 (second sentence).

42. U.C.C. $\$ 3-415(2)$, Comment 3 (fourth sentence) (emphasis added). 
law and equity, including the law merchant ... shall supplement its provisions." 43 He would be a bold man, indeed, who would say that the text of section 3-415(2) has actually displaced the long-established law requiring the contract of a surety--like that of any other obligor-to be supported by a fair consideration. ${ }^{44}$ And this means, if the principles of "law and equity" are really to prevail, that such a case as Carrollton $^{45}$ has not been changed.

Or again, if the "law merchant" is to govern, as alternately provided in section 1-103, the result would be no different. The situation of the "anomalous," or accommodation endorser, a relative newcomer to the law merchant, was greatly perplexed in the last century by other questions: to whom was he liable, and in what capacity? ${ }^{40}$ These issues, however, were well resolved by N.I.L. section 64(1); that is, when he signed before delivery, he was liable as an endorser "to the payee and to all subsequent parties." ${ }^{47}$ That left room for Carrollton, where the endorser signed after delivery; no liability was contemplated in that case by N.I.L. section 64(1). The "intended" version of section $3-415(2)^{48}$ would be excluded.

One trouble, we surmise, is that the draftsmen of section 3-415(2) tried "to fry too many fish" in one short sentence. The cut-off point, "before it is due," is appropriate if the purpose is to reverse Altfilisch v. McCarty ${ }^{49}$ and the other cases holding that a first negotiation after the due date is not necessarily an improper diversion; it has no bearing on the "capacity" question dealt with by N.I.L. section $64 ; 50$ and, on the "consideration" question, it is dead wrong. Fortunately, it is im-

43. U.C.C. \& 1-103. Gilmore writes: "The solid stuff of pre-Code Law will furnish the rationale of decision quite as often as the Code's own gossamer substance." Gilmore, Article 9, 26 LA. L. REv. 285, 286 (1966).

44. Anyone contending for so sweeping a change may not have a burden of proof to meet, bnt at least there should be a strong presumption against him.

45. See text accompanying notes 4-6 supra.

46. See Ingalls v. Marston, 121 Me. 182, 116 A. 216 (1922).

47. N.I.L. $\$ 64(1)$.

48. The Code omitted N.I.L. $\$ 64(1)$ as "unnecessary," all, however, "without any change in substance." U.C.C. $\$ 3-415(2)$, Comment 4. The point is questionable.

49. 49 S.D. 203, 207 N.W. 67 (1926). See note 38 supra. The suggestion in $\$ 3-415(2)$, Comment 3 , that this cut-off point is "one of suretyship law," begs the question. If the accommodation party consents to a first negotiation after maturity, there is nothing in suretyship law to say he would not be liable.

50. An accommodation party who signs as an "indorser," signs in that "capacity" whether the paper is taken before or after maturity. U.C.C. $\$ 3-414$. See note 24 supra. His "liability" is a very different question; we suggest that a taker for value with knowledge that the paper had been fraudulently diverted may not recover against an endorser. It has always been thought necessary, even under N.I.L. $\S 29$, to have holder-in-due-course status in such case. See Gerseta Corp. v. Wessex-Campbell Silk Co., 3 F.2d 236 (2d Cir. 1924). If subsection (2) were to be taken literally, even an infant endorser could be held liable, or a transaction void for usury could be enforced. 
permissible for the comment to shore up the "intended" version of section 3-415(2) by making believe that "antecedent obligations" are some new sort of "consideration."

\section{IV}

\section{U.C.C. $\S 3-408$}

Thus, we have the question whether, as the comment to section 3415(2) asserts, the text of section 3-408 actually does treat "antecedent obligations as consideration." " The material part of section 3-408 reads as follows:

Want or failure of consideration is a defense as against any person not having the rights of a holder in due course (Section 305, except that no consideration is necessary for an instrument or obligation thereon given in payment of or as security for an antecedent obligation of any kind.53

Rather plainly the section does not say that an "antecedent obligation" is some kind of consideration; it says, on the contrary, that "no consideration is necessary" in the special cases described. Moreover, there should be no confusion about it, for the comment clearly states: "'Consideration' is distinguished from 'value' throughout this Article." ${ }^{94}$ This means, to be blunt about it, that the comment to section 3-415(2) is painfully wrong. ${ }^{55}$

More important, a holder cannot brimg the after-acquired contract surety within section 3-408, in order to liold him hable without consideration. As a matter of simple English speech, the phrase, "or obligation thereon," must refer to the word "instrument," with which it is associated in the sentence. It is that imstrument, "or obligation thereon," which is said to require no consideration when it is given for an antecedent obligation. ${ }^{56}$ It thus would be straining things very much to say that the section has any application at all to the Carrollton ${ }^{57}$ facts.

51. Britton is perhaps the source of this confusion, for he used the terms "value" and "consideration" interchangeably: "An antecedent debt constitutes consideration or value for the debtor's own instrument given in payment of or as collateral security therefor." Britron, supra note 8, at 229-30.

52. See text accompanying note 42 supra.

53. U.C.C. \& 3-408 (emphasis added).

54. U.C.C. \& $3-408$, Comment 1. See also note 11 supra.

55. Possibly the writer of U.C.C. \& $3-415(2)$, Comment 3 , belonged to the romantic school of interpretation, rather than the rational, and so may have correctly based the "intended" version of that section on his personal intuitions. We cannot say. See generally R. ARDREY, The Social ConTract 93-101 (1970).

56. \$ 3-408, Comment 2, would seem to agree: 'The 'except' clause is intended to remove the difficulties which have arisen where a note or draft, or an indorsement of either, is given ....."

57. See text accompanying notes 4-6 supra. 
As we read section $3-408,58$ however, an after-acquired surety is to be subject to liability, if his endorsement appears on an instrument that is either "given in payment of or as security for an antecedent obligation of any kind." that "no consideration is necessary." It will be convenient to look first to transfers "in payment of," and then to those "as security for."

\section{A. "In Payment Of"}

If there still are doubts concerning the antecedent of "obligation thereon" in the "except" clause of section 3-408, this illustration should dispel them. Imagine, if you can, a surety who offers to give his bare endorsement "in payment of" some overdue instrument, that is to say, "an antecedent obligation." The offer, of course, would be nonsense; payments are not nuade in that way. ${ }^{60}$

But there is practice to give a check or other instrument in payment of an antecedent obligation. And, of course, such paper may have an endorsement put "thereon" before it is delivered. Without mucl doubt, this is the typical payment situation covered by section 3-408. What the section says is that, while want or failure of consideration would otherwise be a defense, "no consideration is necessary for an instrument or obligation thereon given in paynuent . . . ."01

In the usual case there would be no question of consideration. It requires no authority to say that, when the creditor hands over the past-due note, marked "paid," he has given the bargained-for consideration. ${ }^{62}$ But, if the payment instrument was for only a fraction of the debt, was it adequate? The section firmly closes the door on that question by saying, "no consideration is necessary.""s

As so applied, the section is less than revolutionary. ${ }^{04}$ But is the

58. U.C.C. $\$ 3-408$.

59. The words "of any kind" make it clear that even a contingent liability will suffice. See Griswold v. Morrison, 53 Cal. App. 93, 200 P. 62 (2d Dist. 1921).

60. For one thing, the well-advised payor takes up the instrument when it is paid, and any holder would be reluctant to give it up for a mere endorsement.

61. U.C.C. $\$ 3-408$.

62. Both the "antecedent obligation" and the instrument representing it are discharged. U.C.C. $\$ \S 3-601(3), 3-802(1)(b)$. For early authority see Stewart v. Hidden, 13 Minn. 43 (1868).

63. U.C.C. $\$ 3-408$, Comment 2 (third sentence) makes it clear that this was one purpose of the "except" clause.

64. The draftsmen may have wanted to range beyond commercial paper law, however, to try and settle a disputed point of contract law. That is, it was held long ago in Foakes v. Beer, 9 App. Cas. 605 (1884), that a lesser payment on a contract debt (not represented by an instrument), was inadequate consideration. See A. Corbin, Con- 
debtor, having thus gained a minor point, next to suffer a major defeat? Suppose a check is given, in full, for "an antecedent obligation" growing out of a sales transaction; does the section mean that the buyer has now lost any defense of want or failure of consideration? The seller, for obvious reasons, will not sue on the underlying antecedent obligation, but on the check, if it is not paid. ${ }^{65}$ And, when the buyer offers to slow that the goods were defective, or that no goods were ever dehivered, plaintiff will merely point to section 3-408; it states very clearly that "no consideration is necessary." gue- - that is what the law says. ${ }^{67}$

Again, consider the renewal situation. When the parties to a time note, "an antecedent obligation," agree at maturity to renew it for, say, another year, there is no dearth of consideration in one sense; the old note is delivered up and the renewal, perhaps with an accommodation endorer on it, is given in its place. Does the section mean to say, also, that defenses growing out of the initial transaction are no longer available? According to pre-Code law, the point would have turned, and properly so, on the agreement; if the renewal was made as the equivalent of an "account stated," an initial failure of consideration would, and should, be cut off. ${ }^{68}$ Otherwise not!

What then does this all have to do with after-acquired sureties? For one thing, if failure-of-consideration defenses are to be denied to "an instrument" given by the debtor im payment of an antecedent obligation, as seems to be true, the same reasoning must deny them to any "obligation thereon." There long was a dispute, typified in New York by William Segar, Inc. v. 1967-1975 Ocean Avenue Realty Corp. ${ }^{69}$ whether a niaker's defenses are ever available to a surety. ${ }^{70}$ That ques-

TRACTS $\$ 175$ (1961). Why a check for $\$ 30$ in payment of a simple $\$ 100$ debt should now be adequate, while cash in that amount might still not be, is difficult to explain, but that is for the contracts people.

65. To illustrate the "obvious," such a creditor, when suing on an instrument, now enjoys soine very substantial new procedural advantages. See U.C.C. $\$ 3-307$. If, in addition, he can entirely cut off a buyer's defenses of want or failure of consideration, what could be sweeter?

66. U.C.C. \& 3-408. The coinment says nothing as to whether this was one of the purposes of the section.

67. We have no Code cases so holding, yet.

68. See Wright v. Hage, 214 Ore. 400,330 P.2d 342 (1958), where the authorities are ably discussed. The comment to $\$ 3-408$ does not mention the renewal case or much else.

69. 127 Misc. 805, 217 N.Y.S. 471 (Sup. Ct. 1926). See R. Steffen, Cases on COMMERCIAL AND INVESTMENT PAPER 816-21 (1964).

70. The court in Segar said:

It follows that the defense of absence or failure of consideration would be available to an indorser. The defense pleaded in the case at bar, however, is not one of absence or failure of consideration within the authorities. It is a defense available only to the inaker.

127 Misc. at 810,217 N.Y.S. at 476. 
tion is now laid to rest, if we are correct, both by taking them away from the endorser and, to be doubly sure, by denying them even to the drawer or maker as well.

This is the meat-axe approach. ${ }^{71}$ A more precise method would have been to write the accommodation endorser's contract, if so desired, to warrant a valid and enforceable maker's contract. ${ }^{72}$ Warranties preclude defenses. But the draftsman closed that door by insisting that only an endorser who "receives consideration" makes any warranty, ${ }^{73}$ thus presumably excluding the accommodation endorser. ${ }^{74}$ So, as a matter of practical wisdom, pay your debts in cash before they ripen into "an antecedent obligation of any kind." " 0 , at the very least, put a clause on all your checks: "Defenses Reserved."76

\section{B. "As Security For"}

The maker of a note does not ordinarily sign a second note and give it to his creditor as security for the first. Share certificates and bonds of the debtor to one side, ${ }^{77}$ the transaction is concerned with third-party paper. And, since payment, likewise, may be made by

71. The brash declaration in U.C.C. $\$ 5-505$ that "[n]o consideration is necessary to establish a [letter of] credit or to enlarge its terms," on the other hand, is a master stroke, ending some decades of fruitless debate. See Steffen, "Irrevocable" Credits and the Law, J. Bus. Law 438-43 (1958), reprinted in R. STEFFEN, supra note 69, at 909-14. It must be noted that there is a vast difference between an issuing bank, which lends its credit in a highly organized business, and accommodation parties generally. The bank does right well selling irrevocability.

72. In effect, this is what is done in the case of a transferor endorser; U.C.C. $\S 3-417(2)$ (d) makes such an endorser warrant that "no defense of any party is good against him."

73. U.C.C. $\$ 3-417(2)$. The himitation is new and was evidently designed to exclude an accommodation endorser. But it could easily be argued that an accommodation endorser, who signs before delivery for money to be advanced to the drawer or maker, does "receive" a "consideration" for signing. It is an interesting question. The comment is silent as to why the change was made.

74. Dean Ames thought warranties were appropriate only on transfer, as upon the sale of a horse, and thus could not be made by an accommodation party. For the same reason, he said there could be no warranty upon a presentment for payment or for transfer. See Ames, Forged Transfers of Stock, 17 HaRv. L. Rev. 543 (1904). The Code states a warranty im both these latter cases, U.C.C. $\$ 3-417(1)$ and $\$ 8-306(1)$, but not in the first.

75. U.C.C. $\$ 3-408$. The term "antecedent" is very broad. Perhaps there is no ripening period or only a very short one.

76. What bearing such a clause would have on "negotiability" is a question. It actually does not go as far as "without recourse," which is sanctioned by U.C.C. $\S 3-413(2)$. Prior law allowed the drawer to use a clause "negativing or limiting" his liability. N.I.L. \& 62 .

77. The court in Morris Canal \& Banking Co. v. Fisher, 9 N.J. Eq. 667 (Ch. 1855), had initial doubts whether a borrower's bonds could qualify. See generally Glenn, The Pledge as a Security Device, 24 VA. L. REV. 355 (1938). 
bank draft, or the note of some third person, with or without an endorsement thereon, these cases, too, will be considered.

The comment to section 3-408, first sentence, lumps payment and pledge together, and says the "except" clause is intended to remove certain "difficulties which have arisen." Then, the second sentence states: "The provision is intended to change the result of decisions holding that where no extension of time or other concession is given by the creditor the new obligation fails for lack of a legal consideration." ${ }^{379}$ The comment is otherwise silent as to why any change was felt to be desirable.

"Difficulties" of a sort were encountered in West Rutland Trust Co. $v$. Houston ${ }^{80}$ a leading case. There, the plaintiff trust company, which then held the unsecured note of the Buck Lumber Company, persuaded an employee of the company, the defendant Buck, to put up his personal note, endorsed by defendant Houston, as collateral-so that the transaction would look better when the bank examiner came by. Not an atypical situation, it seems. Buck and Houston defended on the obvious ground that there was no consideration for their signing. While the court had some difficulty, it held for the trust company anyway, upon grounds of public policy: "In such circumstances the defendants are bound as the face of the note discloses." that Buck and Houston were required to pay, while the trust company, which induced the fraud, was not penalized. But the court's holding, based on estoppel, is generally followed. ${ }^{82}$

Conceivably the Code adopted the "no consideration is necessary"83 wording to give further aid to banks in cases of that sort, but we prefer to think not. So, we will assume that the trust company took the Buck-Houston note for a respectable purpose: Let us say it simply wanted to acquire, as cheaply as possible, some additional security; or, it had an idea of using the principal note, with the new

78. U.C.C. $\$ 3-408$, Comment 2.

79. Id. This sentence compares with $\S 3-415(2)$, Comment 3 (sentence 2), discussed in text accompanying note 7 supra. Here one new idea has been introduced; there are some unstated "difficulties" to overcome.

80. 104 Vt. 204, 158 A. 69, 80 A.L.R. 664 (1932).

81. $104 \mathrm{Vt}$. at $208,158 \mathrm{~A}$. at 72 ("Transactions with banks are affected with an unusual publie interest").

82. Where the bank has not failed, however, many courts refuse recovery on traditional grounds. First Nat'l Bank v. Reed, 198 Cal. 252, 244 P. 368 (1926), was such a case:

Estoppel cannot be relied upon to create a liability, in a situation where, as here, the agent [of the bank], acting solely for the benefit of his principal, actively participated in the deceit and fraud, and solicited the act from the person sought to be estopped by the principal.

198 Cal. at 261, 244 P. at 371.

83. U.C.C. $\$ 3-408$. 
collateral, for rediscount purposes. What "difficulties" might it then encounter?

The first thing to note is that the trust company would have taken the paper for "value." Ever since Swift $v$. Tyson, ${ }^{84}$ this has been so. The trust company would be said to have a "hen"85 on the Buck-Houston note, for no court, in a century or more, has required a consideration to support a pledge. If the trust company acted in good faith and without notice, ${ }^{86}$ it would be a holder in due course, even though it was a payee. This has been true at least since Liberty Trust Co. v. Tilton, ${ }^{87}$ decided in 1914. The Code now expressly affirms: "A payee may be a holder in due course." 88 Thus, the trust company would seem to have no real "difficulties," at least as respects Houston.

In 1920 there was a confused Illinois case, Elgin National Bank v. Goecke, ${ }^{89}$ in which the court did have difficulty in reaching a decision, that is, a decision for the bank. There, the defendant accommodation endorsers of a $\$ 3,000$ note, made by Elgin Brewing Company, had signed with the express understanding that the note was to be used only for company purposes. Instead, the defendant Goecke, the company president, wrongfully pledged the note as collateral for his own personal debt to the bank. Very probably Elgin National Bank could not have qualified as a holder in due course; when an officer pledges a company note for his own personal purposes, the taker is at least put upon inquiry. ${ }^{90}$ The court, however, had resort to N.I.L. section 29, which, like U.C.C. section 3-415(2), can be construed to say that an accommodation party is hable to a mere "holder for value,"01 no matter what defenses may be pleaded. We prefer to disassociate ourselves from that construction. ${ }^{92}$

Before going on, however, it will be noted that the Illinois court faced no real "difficulties." That is, this is true if we abandon the false premise that banks must always win. If the bank had acted in good faith and without notice of the fraud, it could have recovered as a

84. 41 U.S. (16 Pet.) 1 (1842).

85. N.I.L. \$ 27; U.C.C. \$ 3-303(b).

86. The Code is careful to say, in accord with prior law [N.I.L. \& 29], that an accommodation party may be liable to a holder for value "even though the taker knows of the accommodation." U.C.C. \& 3-415(2). If the "taker" also knows that the accommodation party signed after delivery and without consideration to fool the bank examiner, we suggest the taker acted with notice of fraud, and should not recover.

87. 217 Mass. 462,105 N.E. 605 (1914).

88. U.C.C. $\$ 3-302(2)$.

89. 295 III. 403,129 N.E. 149 (1920).

90. Rochester \& C.T. Rd. Co. v. Paviour, 164 N.Y. 281, 58 N.E. 114 (1900).

91. N.I.L. $\$ 29$. The Code retreats even here and gives rights to a person who is not a holder, but who has merely "taken for value." U.C.C. \$ 3-412(2).

92. See text accompanying note 50 supra. 
holder in due course. Thus, even the supposed difficulties of Elgin National Bank could not well have been a reason for the "except" clause. $^{93}$

The action against employee Buck, the accommodation maker in our illustration, presents a different question. But the common law courts, here too, had few "difficulties." For example, in Kiess v. Baldwin ${ }^{94}$ husband Kiess was indebted to the Commercial National Bank of Washington in an amount of $\$ 12,352.20$ for securities purchased. Thereafter, and for no discernible consideration, except possibly "love and affection," the defendant wife was induced to give the bank her personal note for the debt as security. "Under those circuunstances," Chief Justice Martin said, "the defendant was not liable upon the note. . ..."95

Moreover, the Code would give the same answer, apart from the "except" clause. Granting that the Commercial National Bank, as payee, would be a holder in due course, its rights are stated in section 3-305(2);96 it would take Mrs. Kiess' note free from "all defenses of any party to the instrument with whom the holder has not dealt . . . .997 Which means, rather plainly, that as between immediate parties all the traditional defenses-fraud, failure of consideration, nondelivery, usury-are still available. And, if so in the case of a holder in due course, why not in that of a mere "taker" for value?

Turning to the payment situation, we agam find no real "difficulties." ${ }^{98}$ If a bank draft is used by the obhgor, it may constitute "absolute" payment, ${ }^{99}$ in spite of Lord Holt's assertion, long ago, that a paper promise can never be payment. ${ }^{100}$ Aside from that, when the paper is handed to another to remit to the creditor, there has been authority since Chat v. Edgar ${ }^{101}$ permitting the good-faith purcliaser to recover from the drawer, free of any defense of failure of consideration between drawer and remitter.

Even when a third person pays witli his personal check or note, dehivered directly to the creditor, there may be no real trouble. The

93. U.C.C. \& 3-408.

94. 74 F.2d 470 (D.C. Cir. 1934).

95. Id. at 472.

96. U.C.C. \& 3-305(2).

97. Id.

98. U.C.C. $\$ 3-408$, Comment 2.

99. U.C.C. \& 3-802(1)(a). See also Hamilton v. R.S. Dickson \& Co., 85 F.2d 107 (2d Cir. 1936). In other cases, also, the instrument may be absolute payment, if the facts warrant that result.

100. Ward v. Evans, 92 Eng. Rep. 1002 (K.B. 1702).

101. 83 Eng. Rep. 1156 (K.B. 1663). See also Boston Steel \& Iron Co. v. Steuer, 183 Mass. 140, 66 N.E. 646 (1903) (a leading pre-Code case); U.C.C. § 3-302(2), Comment 2a. 
Code provides in such case, as less certainly at common law, that the payment iten operates to "suspend" the principal obligation, at least pro tanto, until the payment instrument "is due or if it is payable on deinand until its presentment."102 Thereafter, if the instruinent is not paid, "action may be maintained on either the instrument or the obligation." 103 What inore could an honest creditor ask?

Of course, the creditor ultimately wants inoney. If he chooses to sue on the principal obligation, he will be met with whatever coinmon law defenses were available at the start. But are these now available to the after-acquired surety on his payinent note or check? We have no Code cases, but the logic of the argument so far would say that they are cut off. When the surety asks the creditor to suspend whatever action he may have against the principal debtor, for one day or one year, and the creditor does that, there would seein to be no question of consideration left to argue about. It would seem the surety must pay-even if lie did make a bad bargain-and look to the accommodated party for indemnity.

We recognize that the same argument can be inade when the debtor gives his own note or cleck. ${ }^{104}$ In the renewal cases, discussed above, it might have some validity. But, while the debtor's own check may also operate to "suspend" action, this is scarcely the same case as when a third person bargains for time for the debtor. On nonpayment of the debtor's own check, we would prefer to put the parties back in status quo ante, with no defenses barred. ${ }^{105}$ If not, the debtor has a second reason for putting "Defenses Reserved"100 on his payment items.

\section{FINALLY}

We recomniend that the "except" clause of section 3-408107 be repealed forthwith. As above construed, it is possible to hive with sec-

102. U.C.C. $\$ 3-802(1)(b)$.

103. Id.

104. In Mansion Carpets, Inc. v. Marinoff, 24 App. Div. 2d 947, 265 N.Y.S.2d 298 (1965), where suit was by payee against drawer on a check, the question was squarely raised. The court simply disregarded the "except" clause of $\$ 3-408$ and said, "Want or failure of consideration is a defense . . ." 24 App. Div. 2d at 947, 265 N.Y.S.2d at 299. See also Brotherton v. McWaters, 4 U.C.C. REP. SERv. 1155, 39 Okla. ST. B.J. 225 (1968).

105. See McKensie v. Oregon Improvement Co., 5 Wash. 409, 31 P. 748 (1892) (common law rule). See also Wickham, Consideration and Value, 3 Wast. L. Rev. 321, 324-25 (1926).

106. See note 76 supra and accompanying text. We do not know what "Defenses Reserved" may come to mean, bnt its purpose is to preserve to the drawer his contract defenses as against the payee-creditor.

107. U.C.C. \& $3-408$. 
tion 3-415(2), ${ }^{108}$ though the section should be called back sometime and unscrambled. But the "except" clause is something quite new to our jurisprudence ${ }^{109}$ and, we suspect, will result in more harm than good.

Whether we have canvassed all the "difficulties"110 which the draftsmen may have had in mind is not certam. But, to us, the discussion boils down to one simple issue. Neither section 3-415(2) ${ }^{111}$ nor 3-408 ${ }^{112}$ can help the creditor who seeks to ensnare casual endorsers, such as Latting in the Carrollton case. ${ }^{113}$ That seems clear enough. The Mrs. Kiesses ${ }^{114}$ of this world, however, who overgenerously give their personal notes to bank creditors as security, are vulnerable; that is, a creditor armed with the "except" clause of section 3-408 inay now be able to force them to pay, without consideration. ${ }^{115}$

The Code gives no reason why this should be so and we have found none. Britton, however, inakes two arguments, both specious, which may have influenced the draftsinen. His more engaging point is that the whole thing is just a "inere accident",116 if Mrs. Kiess, for example, had made "the instrument payable to the debtor who in turn would indorse it to his creditor,"117 she might have been hable anyway. Then follows his second point: "Substantive differences should not turn on such delicate differences of form." 118

108. U.C.C. \& 3-415(2). See text accompanying notes 43-48 supra.

109. The comment to $\S 3-408$ states that it is based on N.I.L. Sections 24,25 , and 28 "combined and reworded." Some rewording! One may search those three sections until blne in the face, without finding even a hint of the "except" clause.

110. See text accompanying note 78 supra. We have not reviewed the cases where the court has had trouble with the consideration doctrine as such. Whether "love and affection" is consideration, is scarcely a commercial paper question. See, e.g., Meyer v. Meyer, 379 IIl. 97, 39 N.E.2d 311 (1942); Schuman-Heink \& Co. v. United States Nat'l Bank, 108 Cal. App. 223, 233-35, 291 P. 684, 688 (4th Dist. 1930).

111. U.C.C. $\$ 3-415(2)$.

112. U.C.C. $\S 3-408$.

113. See text accompanying notes 4-6 supra.

114. See text accompanying notes 94-95 supra.

115. See First Nat'l City Bank v. Valentine, 7 U.C.C. REP. SERv, 53 (N.Y. 1969). Mrs. Valentine was induced to endorse her husband's mortgage note, apparently before delivery to plaintiff bank, upon the pious fraud that "it was a matter of form and the mortgage would never be foreclosed." The court cited sections 3-408 and 3-415(2) and struck out Mrs. Valentine's affirmative defense of no consideration: "[A]t the present time an antecedent debt of the maker is sufficient consideration to bind an accommodation endorser of a negotiable instrument."

116. W. BRTtTon, BILLS AND Notes, supra note 8, at 231. This "mere accident" argument has no terminus; according to it the holder who by mere accident fails to make timely presentunent would not lose secondary parties. U.C.C. $\$ 3-501$ views this matter coldly.

117. W. BRItron, supra note 8, at 231. "To free the surety in these few cases serves no useful purpose." In fact, it would give the "shrewd one . . . a chance to make a pretense of helping out a debtor," at uo cost. All just lovely fantasy, as we read the cases.

118. Id. 
Here Britton is partly right, for the creditor in such case might well recover as a holder in due course. ${ }^{119}$ This assumes, however, that when Mrs. Kiess laid the matter before her husband, he would go along with the deal. But, why should he, unless the creditor were to agree to release other collateral or to make some reasonable concession? Moreover, in a realistic world the well-advised creditor will take the initiative and do just that, in order to avoid "accidents" of the sort that let Mrs. Kiess escape in Kiess v. Baldwin. ${ }^{120}$ So, why the "except" clause?

Britton's second point may have been more persuasive. But his suggestion that there really are only "delicate differences of form" between holders in due course and mere takers for value shows little regard for realities. The concept of a bona fide purchaser, or holder in due course, ${ }^{121}$ has been one of slow growth, fashioned in many hard-fought trials; ;22 the taker for value, on the other hand, is an illdefined upstart, spawned by the unfortunate description of "accommodation party" in N.I.L. section 29 . Indeed, there is not even a requirement of "good faith" in the case of the "taker."123 And now, with the "except" clause in hand, his position is greatly strengthened; no consideration is necessary either. ${ }^{124}$ This is doubtful policy at any time; ${ }^{125}$ it is especially so when even the holder in due course has come under fire. ${ }^{126}$

On the payment side, we seem to be progressing backwards. At the start of the 18th century, the creditor's counsel insisted that a promissory note was a common law specialty-with consideration defenses denied. ${ }^{127}$ Fortunately, Lord Holt was emphatically opposed to that idea. ${ }^{128}$ Then, for much of the 19 th century, the question was a procedural one: whether the debtor must bring a separate action to assert his defenses. ${ }^{129}$ That issue was finally settled by N.I.L. section 28 ; ab-

119. See text accompanying note 88 supra.

120. 74 F.2d 470 (D.C. Cir. 1934).

121. N.I.L. $\$ 52$; U.C.C. $\$ 3-302$. Compare the term "bona fide purchaser," defined in U.C.C. $\$ 8-302$.

122. An illustration is the question of "good faith." See Murray v. Lardner, 69 U.S. (2 Wall.) 110 (1864), which established the "subjective" test.

123. See Elgin Nat'l Bank v. Goecke, 295 Ill. 403,129 N.E. 149 (1920). Nor does U.C.C. $§ 1-203$ fill the gap; it inerely requires "good faith" in the "performance or en. forcement" of a "contract" or a "duty."

124. U.C.C. \$ $3-408$.

125. See generally W.O. Douglas, Points of Rebellion 47 (1970); Justice Mey. er's misgivings are discussed at note 18 supra.

126. Many states now have statutes designed to protect the consumer against holders in due course. E.g., The Unruh Act, CAL. Crv. Code $\$ 1804.2$ (West 1954). See also Alcoa Credit Co. v. Nickerson, 5 U.C.C. REP. SERV. 152 (Mass. 1968).

127. The point is discussed in J.M. HoldEN, History OF Negotiable INSTRUMENTS 78 et seq. (1955).

128. Clerk v. Martin, 91 Eng. Rep. 122 (K.B. 1702).

129. See Parish v. Stone, 14 Pick. 198, 25 Am. Dec. 378 (Mass. 1833). 
sence or failure of consideration is a defense. ${ }^{130}$ Now, the Code solemnly reaffirms the N.I.L. position, by the first two lines of section $3-408,{ }^{131}$ but then, by the "except" clause, returns full circle to say that, of course, no consideration is necessary anyway. ${ }^{132}$

Whatever else, it is difficult to square the "except" clause of section 3-408 with the general purposes of the Code. ${ }^{133}$ The clause has done little either to "simplify," "clarify," or "modernize" the law of commercial transactions. If anything, it has done the contrary. How this came about is not clear. Our guess is that the draftsmen simply became bemused with their own phrase: "Antecedent Obligation of Any Kind."134 It is so rotund and prosperous looking; surely it must imply a consideration of some sort. ${ }^{135}$

One is reminded, someliow, of the case of Francis v. McNeal, ${ }^{136}$ where it was urged with much confidence that a partnership is an Entity, and hence that only it could be brought before the bankruptcy court. But through the haze, Justice Holmes saw the faces of the imdividual partners $i m$ the background. So here, we are dealing with creditors, in the ancient debtor-creditor equation, not with some mystifying concept: Antecedent Obligation of Any Kind. It will be good to be rid of the phrase.

All said and done, the Code is a splendid achievernent. ${ }^{137}$ It is not perfect; very few things are. In our view, it may be improved appreciably by deleting altogether the 26 words comprising the "except" clause of section 3-408. They serve no useful purpose and may very well produce some mischief; certainly they will never be missed by the right-dealing ${ }^{138}$ bank or merchant creditor.

130. But, very inuch in the creditor's favor, the burden of proving no consideration was lodged with the debtor. See Kessler v. Valerio, 102 Conn. 620, 129 A. 788 (1925), noted in 35 YALE L.J. 368 (1926).

131. U.C.C. $\$ 3-408$. And, puts the burden on the maker by $\S 3-307(2)$.

132. That is, the obligor is liable, even as in the case of a common law specialty.

133. See note 28 supra and accompanying text.

134. U.C.C. $\S 3-408$.

135. As some writers have said. See note 10 supra.

136. 228 U.S. 695,699 (1913).

137. We would single out $\$ 3-302(2)$, coupled with $\S 3-306(2)$, stating the rights of a payee as a holder in due course, and $\$ 3-802$, concerning the effect of payment by instrument. Both are examples of nice draftsmanship. Indeed, as discussed above, they have alone eliminated much of the supposed need for the "except" clause of $\$ 3-408$. Such a case as Strong v. Sheffield, 144 N.Y. 392, 39 N.E. 330 (1895), which bedeviled several generations of law students, yields to $\$ 3-302(2)$.

138. J. Marius, Advice Concerning Bulls of Exchange (1651): "[T] deahing merchant doth not care how little he hath to do in the common law or things of that nature." 


\title{
California Law Review
}

\begin{tabular}{lll}
\hline \hline Vol. 59 & November 1971 & No. 6 \\
\hline \hline
\end{tabular}

\section{BOARD OF EDITORS}

\author{
Editor-in-Chief \\ Dennis S. KarJaLA \\ Managing Editor \\ David L. HammetT
}

Notes \& Comments ROBERT C. BARRETT LAWRENCE R. BROWN HENRY C. EAMES, JR. AUbaN ANN EISENhaRdT JAMES C. FOWLER ELAINE T. NeLSON ReX PERSCHBACHER ROBERT K. SCHIEBELHUT Ass't Managing Editor HaRold G. FriedmaN

DAVID M. ACHTERKIRCheN JoHN F. Davis ChARLES R. FARRAR, JR. ROBERT L. HARRIS

JEFFREY M. ALIEN MICHAEL J. BARER Alice M. BEAsLey Steven S. Bell Michael J. BertinetTI MARSha Siegel Berzon DAVID F. Boyle GABRIELle R. CAMPBeli WILLIAM F. CAPPS Craig H. Casebeer Raymond A. DIAZ JOSEPH P. DICIUCCIO MARK S. DODSON

\author{
Articles \& Book Reviews \\ JIMMIE HARRIS \\ CAROL BRUCH Myers \\ LYNN H. PASAHOW \\ STEPHEN ZAMORA \\ Research \\ STEVEN A. Brick \\ RICHARD MARCUS \\ Supreme Court Editor \\ Carol G. HammetT
}

Associate Editors

SPENCER R. KaItz

THOMAS M. MURRAY

LANCE JAY ROBBINS

Thomas B. RosenberG

Paul E. Dorroh

JAMES DRUMMY

IRa MARx ELlmaN

KenNETH JAMES Fishbach, JR.LARY LAWRENCE

ERNESTINE FORREST

HowARD W. Foss, JR.

David M. GLass

SAMUEL GROSS

Peter Grossman

LESLIE ANN JOHNSON

RICHARD KALISH

Administrative Assistant

PAtricia G. SMith
ZONA SAGE

Mark Harold Shenfield

SUSAN J. TAMURA

SCOTT R. WILLERT

JACK H. KAUfMAN, JR.

KeVIN F. Kelly

STEPHEN L. KostKA

DANIEL J. Leer

PALMer Brown MAdDEN

CRAIG D. MILLER

Oscar Parra

Thomas E. RANkIN

Lee Charles Rosenthal

Craig M. Thomas

JOHN E. THORSON

STEPHEN J. YODER 